\title{
JEDNA Z MOŻLIWOŚCI KSZTALTOWANIA CHARAKTERYSTYKI ROZPRASZANIA ENERGII W KONSTRUKCJI SAMOCHODU
}

\author{
KAZIMIERZ M. ROMANISZYN² ${ }^{2}$ MICHAL SZUBERLA'
}

Akademia Techniczno - Humanistyczna w Bielsku Białej

\section{Streszczenie}

W publikacji opisano jak ważną rolę w wyborze samochodu przez klienta stanowi czynnik bezpieczeństwa. Opisano również główne czynniki dotyczące kształtowania bezpieczeństwa biernego samochodu i wytyczne badawcze dotyczące metod tej oceny. Omówiono spotykane przebiegi rozpraszania energii w zależności od przebiegu zgniotu nadwozia przy uderzeniu czołowym. Wskazano na przebiegi o charakterze korzystnym i niekorzystnym dla przeżycia ludzi wewnątrz nadwozia. Dla ukształtowania korzystnej charakterystyki rozpraszania energii zaproponowano własne rozwiązanie konstrukcyjne belki podłużnej w konstrukcji nadwozia. Poprawę przebiegu rozpraszania energii uzyskano przez wzmocnienie wykonanych próbek podłużnic specjalnymi elementami przyspawanymi do ścianek podłużnic. Założono przy tym, że przez rodzaj spoiny można wpływać na krzywą rozpraszania energii. Wykonano próbki i poddano je badaniom na maszynie wytrzymałościowej w certyfikowanym laboratorium Instytutu Badań i Rozwoju Motoryzacji BOSMAL w Bielsku Białej. Zaprezentowano przebiegi rozpraszania energii dla próbki bez wzmocnień i ze wzmocnieniami. Porównano i oceniono uzyskane wyniki zarówno pod względem jakościowym i ilościowym. Publikacja powstała na bazie pracy dyplomowej studenta M. Szuberli, promotor; K.M. Romaniszyn.

Słowa kluczowe: bezpieczeństwo bierne, rozpraszanie energii.

\section{Wprowadzenie}

Ogólne zagadnienia związane z bezpieczeństwem należą obecnie do najważniejszych kryteriów oceny samochodów zarówno z punktu widzenia projektantów, konstruktorów, jak i klientów salonów samochodowych. Dynamiczny rozwój rynku motoryzacyjnego powoduje zwiększające się natężenie ruchu drogowego, a co za tym idzie wzrost liczby wypadków. Dlatego coraz więcej osób kupujących nowe samochody zwraca uwagę nie tylko na aspekty ekonomii, czy bezawaryjności, ale kieruje się poziomem bezpieczeństwa, jaki oferuje im dany model pojazdu $[1,3]$. Na rysunku 1 zestawione są preferencje klientów, którymi kierują się przy zakupie nowych samochodów w kilku wybranych państwach.

\footnotetext{
'Akademia Techniczno-Humanistyczna w Bielsku-Białej, Katedra Silników Spalinowych i Pojazdów, ul. Willowa 2, 43-309 Bielsko-Biała, e-mail: kromaniszyn@ath.bielsko.pl, tel.: 3382793 49, wew. 234

${ }^{2}$ Akademia Techniczno-Humanistyczna w Bielsku-Białej, Wydział Budowy Maszyn i Informatyki,

ul. Willowa 2, 43-309 Bielsko-Biała, e-mail: mic.szu@poczta.onet.pl, tel.: 660715574
} 


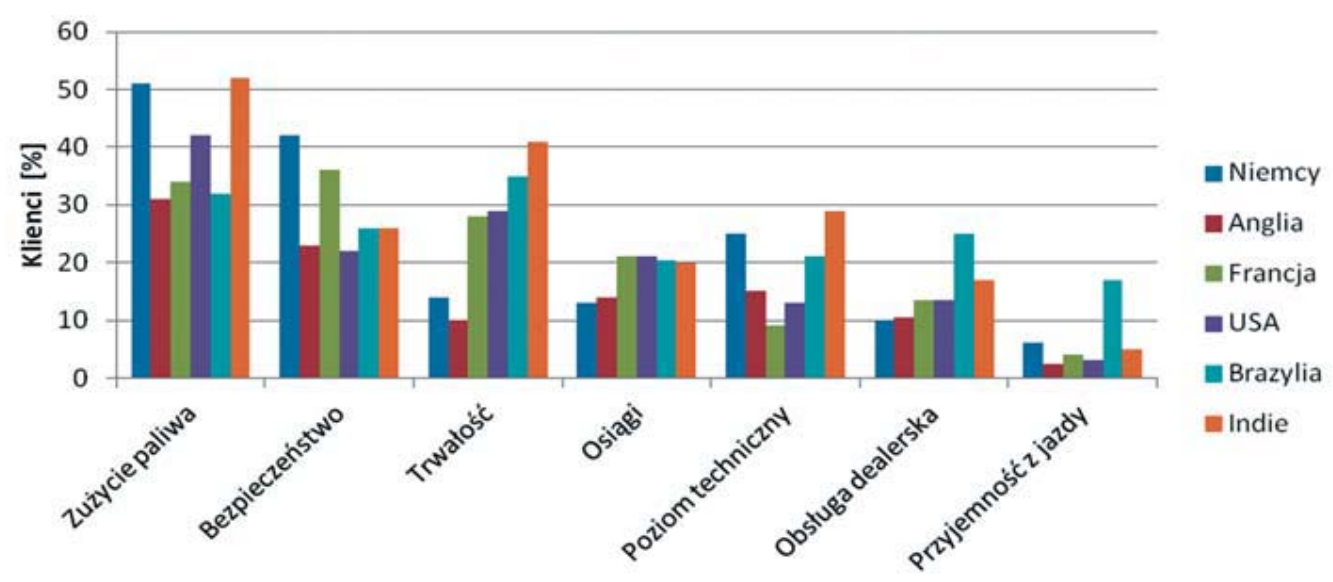

Rys. 1 Preferencje klientów przy zakupie samochodów [1]

Można zauważyć, że w krajach zamożnych, takich jak Niemcy, Francja, Anglia czy USA, bezpieczeństwo jest jednym z głównych czynników, którymi kierują się nabywcy nowych samochodów. Z kolei kupujący z państw uboższych w większym stopniu cenią sobie niskie zużycie paliwa oraz trwałość.

Analiza danych statystycznych wypadków drogowych wykazuje najwyższy (ponad 60\%) udział zderzeń czołowych w ogólnej ich liczbie (rys.2). Jest to czynnik wymuszający na konstruktorach, aby dużą część uwagi skupiali na odpowiednim ukształtowaniu przedniej części pojazdów - konstrukcja powinna zapewniać kontrolowane pochłanianie energii uderzenia. Realizacja tego zadania jest uzależniona od umiejscowienia silnika w obrębie nadwozia pojazdu. Gdy znajduje się on w przedniej jego części, powoduje zwiększenie nacisku na przednią oś i podczas wypadku samochód wykazuje tendencję do "nurkowania", czyli wsuwania się pod drugi samochód uczestniczący w kolizji. W przypadku

\section{घZderzenie czołowe $\quad$ Zderzenie boczne $\quad$ Przewrócenie $\quad$ Zderzenie tylne}

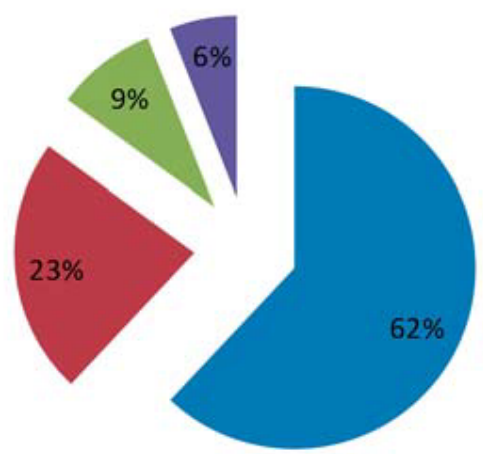

Rys. 2 Statystyka wypadków drogowych wg Daimler AG [2] 
umieszczenia silnika z tyłu, przód pojazdu jest odciążony, co zmienia charakterystykę zderzenia. Jednostka napędowa posiada dużą masę, z czym wiąże się powstawanie w trakcie zderzenia znacznych sił bezwładności, które w przypadku umieszczenia silnika z tyłu, wpływają na zgniatanie części pasażerskiej.

Dużo trudniejszym wyzwaniem jest zapewnienie energochłonności w przypadku zderzeń bocznych, które (jak wskazują statystyki) występują w ponad 20\% przypadków. Głównie są to zderzenia z innymi pojazdami lub obiektami przydrożnymi, np. drzewami, słupami itp. 0 ile w sytuacji zderzenia bocznego z udziałem innego samochodu pochłania on część energii, w przypadku zderzenia z drzewem lub słupem cały impet uderzenia przyjmuje boczna część nadwozia. Czynnikiem niekorzystnym jest także niewielka odległość kierowcy od zewnętrznego, bocznego obrysu pojazdu, co wiąże się z koniecznością stosowania sztywniejszych wzmocnień, których zadaniem jest przekazanie energii uderzenia na inne elementy struktury nadwozia. W niniejszym opracowaniu odniesiono się do poprawy bezpieczeństwa przy najczęściej występujących uderzeniach czołowych.

\section{Czynniki kształtujące bezpieczeństwo bierne}

$\mathrm{Na}$ terenie Europy obowiązują postanowienia Europejskiej Komisji Gospodarczej (ECE) Organizacji Narodów Zjednoczonych, w ramach której w 1953 roku rozpoczęła pracę Grupa Robocza Ruchu Drogowego i podległa jej Grupa Ekspertów w zakresie budowy pojazdów. Podstawowym dokumentem jest „Porozumienie dotyczące przyjęcia jednolitych przepisów technicznych dla pojazdów kołowych, wyposażenia i części, które mogą być montowane i/lub użyte w pojazdach kołowych oraz warunków wzajemnego uznawania homologacji udzielonych na podstawie tych przepisów" (Genewa 1958r.).[2]

Ponadto Unia Europejska posiada własne normy prawne zestawione w tzw. dyrektywach EWG. Część z nich pokrywa się z wymaganiami ECE.

W poniższej tabeli zestawione są przykładowe dyrektywy UE i odpowiadające im regulaminy ECE z zakresu bezpieczeństwa samochodów osobowych.

Tablica 1. [4]

\begin{tabular}{|l|c|c|}
\hline \multicolumn{1}{|c|}{ Przedmiot homologacji } & Dyrektywa UE (EWG) & Regulamin ECE ONZ \\
\hline $\begin{array}{l}\text { Zabezpieczenie kierowcy przed uderzeniem } \\
\text { o kierownicę przy zderzeniu czołowym }\end{array}$ & $74 / 297 / \mathrm{EEC}$ & $\mathrm{R} 12$ \\
\hline Hamowanie samochodów osobowych & $71 / 320 / \mathrm{EEC}$ & $\mathrm{R} 13-\mathrm{H}$ \\
\hline Pasy bezpieczeństwa i urządzenia przytrzymujące & $77 / 541 / \mathrm{EEC}$ & $\mathrm{R} 16$ \\
\hline Mocowanie pasów bezpieczeństwa & $76 / 115 / \mathrm{EEC}$ & $\mathrm{R} 14$ \\
\hline Wytrzymałość siedzeń, ich kotwiczeń i zagłówków & $74 / 408 / \mathrm{EEC}$ & $\mathrm{R} 17$ \\
\hline Krawędzie zewnętrzne pojazdu & $74 / 483 / \mathrm{EEC}$ & $\mathrm{R} 26$ \\
\hline $\begin{array}{l}\text { Zabezpieczenie pasażerów w razie zderzenia } \\
\text { czołowego }\end{array}$ & $96 / 79 / \mathrm{EC}$ & $\mathrm{R} 94$ \\
\hline $\begin{array}{l}\text { Zabezpieczenie pasażerów w razie zderzenia } \\
\text { bocznego }\end{array}$ & $96 / 27 / \mathrm{EC}$ & $\mathrm{R} 95$ \\
\hline
\end{tabular}


Zapewnienie bezpieczeństwa biernego jest tożsame z ograniczeniem skutków zaistniałego wypadku. Głównym celem jest ochrona życia kierowcy i pasażerów, a także minimalizacja ryzyka wystąpienia poważnych obrażeń.

Realizacja powyższych wymagań możliwa jest poprzez stosowanie:

- odpowiedniej konstrukcji nadwozia (część przednia i tylna - pochłaniające jak największą energię uderzenia; część środkowa - stanowiąca tzw. klatkę przeżycia, czyli konstrukcję sztywną i wytrzymałą), ponadto wzmocnienia drzwi bocznych, słupków, progów oraz dachu,

- bezpiecznych zamków w drzwiach bocznych (uniemożliwiających ich samoczynne otwarcie podczas wypadku, a jednocześnie zapewniających możliwość otwarcia drzwi po wypadku),

- bezpiecznych szyb - nie powodujących kaleczenia pasażerów w przypadku uszkodzenia oraz umożliwiających ich bezpieczne wypchnięcie po wypadku,

- podatnej kolumny kierowniczej, zaprojektowanej w sposób zapobiegający przemieszczeniu się jej do wnętrza pojazdu podczas wypadku,

- pasów bezpieczeństwa z napinaczami sterowanymi elektronicznie oraz ogranicznikami siły ich napięcia,

- poduszek gazowych (kierowcy i pasażera, bocznych, chroniących głowy oraz kolana),

- foteli przednich wyposażonych w zagłówki (aktywne zagłówki) z możliwością regulacji wysokości podparcia głowy,

- bezpiecznego zbiornika paliwa (odcinającego dopływ paliwa w razie wypadku oraz wyposażonego w mechanizm blokujący jego wypływ po przewróceniu samochodu),

- instalacji elektrycznej z możliwością odłączenia źródła mocy (akumulatora) po zderzeniu,

- wnętrza nadwozia wykonanego z materiałów miękkich, niepalnych, odpowiednio wyprofilowanych, wg odpowiednich norm bezpieczeństwa.

Nadwozia współczesnych samochodów nie charakteryzują się jednakową sztywnością na całej długości. Podyktowane jest to koniecznością istnienia stref pochłaniających znaczną część energii podczas zderzenia. W przypadku zderzenia czołowego energię przejmują kolejno: zderzak, pas przedni, podłużnice i nadkola. W obrębie samochodu można wyróżnić trzy podstawowe strefy zbudowane w oparciu o zasadę gradacji sztywności. Należą do nich energochłonne - przednia i tylna część pojazdu oraz sztywny i wytrzymały przedział pasażerski, stanowiący tzw. klatkę przeżycia dla kierowcy i pasażerów. Przykład części składowych przedziału pasażerskiego przedstawia rysunek 3. Jednym z prekursorów obliczeń klatek przeżycia był J. Pawłowski [5], który opracował metodykę obliczeń zwaną PPK.

Wydzielenie w/w stref jest możliwe dzięki stosowaniu zróżnicowania zarówno pod względem materiałów, z których wykonane są poszczególne części nadwozia, jak i nadawaniu im specjalnych kształtów. W przypadku zderzenia czołowego, energię przejmują - zderzak, pas przedni, poprzecznica, podłużnice i nadkola (rys. 4). Ich zadaniem jest także przekazanie sił do węzłów konstrukcyjnych, skąd rozchodzą się po klatce chroniącej przedział pasażerski (nie mogą jednocześnie powodować jej deformacji). Politechnika Świętokrzyska jest organizatorem cyklicznych konferencji dotyczących bezpieczeństwa ruchu. W zeszytach naukowych tej uczelni można znaleźć wiele publikacji autorstwa profesorów: Jerzego 


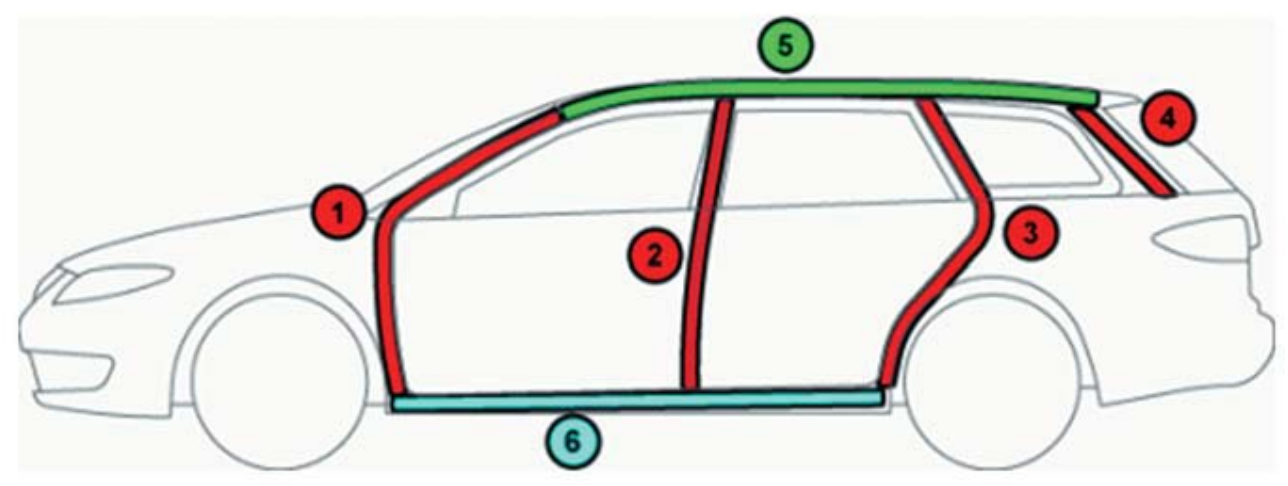

Rys. 3. Schemat klatki przeżycia dla kierowcy i pasażerów [6]

1-słupek $A$; 2-słupek B; 3-słupek $C$; 4-słupek $D$; 5-wzmocniona konstrukcja dachu; 6-wzmocniona konstrukcja podłogi i progów

Wichra, Zbigniewa Lozi i Leona Prochowskiego, dotyczących zagadnień bezpieczeństwa biernego, w tym również dyssypacji energii przy odkształceniach nadwozia.

Podłużnice odgrywają szczególnie istotną rolę, ponieważ to głównie one odpowiadają za pochłonięcie energii zderzenia [11]. Odbywa się to poprzez specjalne kształty, przekroje, wymiary oraz materiały z jakich są tworzone. Ponadto posiadają konstrukcyjnie „zaprogramowane" miejsca odkształcenia. Wszystko po to, aby przebieg rozpraszania energii zachodził w sposób kontrolowany.

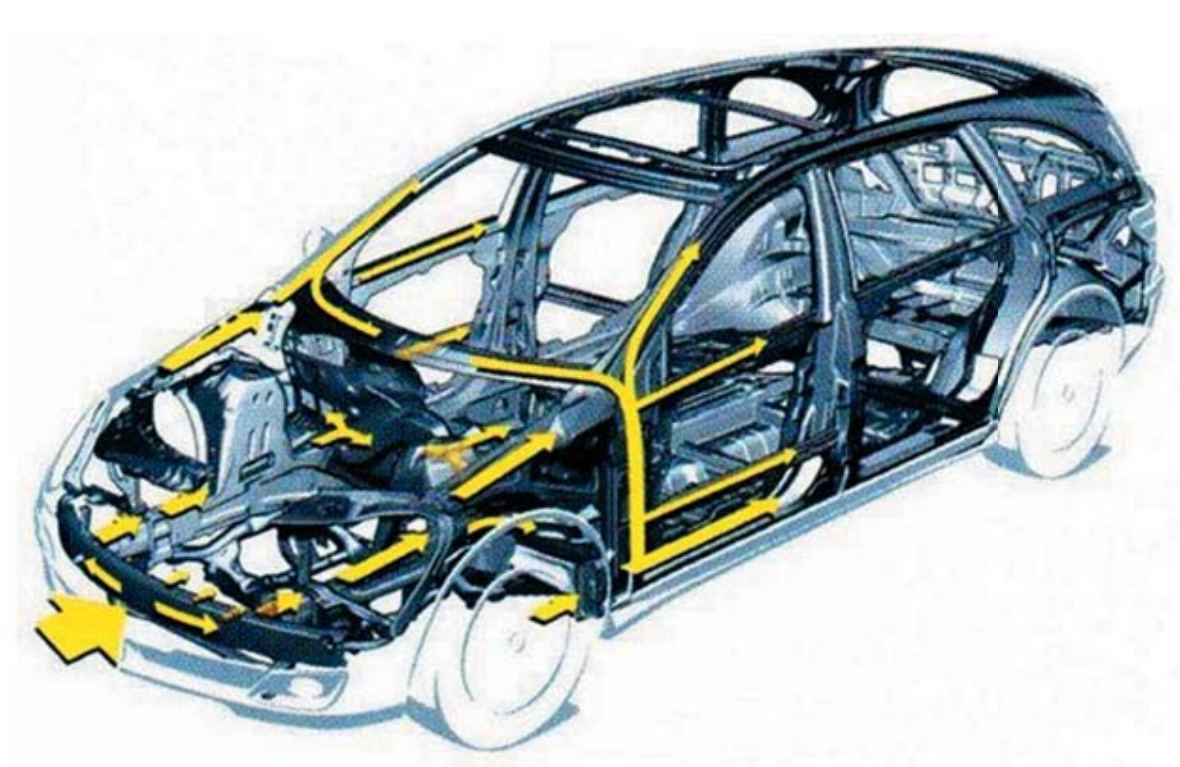

Rys. 4. Rozkład sił na poszczególne części nadwozia podczas zderzenia czołowego [4] 


\section{Rozpraszanie energii przez elementy nadwozia}

Nadwozie nowoczesnego samochodu osobowego jest tak zaprojektowane, aby w wyniku zderzenia ulegało procesowi kontrolowanej deformacji w strefach do tego przewidzianych. Istotą takiego rozwiązania jest konieczność pochłonięcia jak największej energii wypadku przed przestrzenią pasażerską. Powoduje to zmniejszenie przyspieszeń oddziałujących na pasażerów do akceptowalnych przez organizm wartości. Na rysunku 5 przedstawiony jest wykres ilustrujący różnicę rozkładu przyspieszeń nadwozia przy zderzeniu czołowym z prędkością około $50 \mathrm{~km} / \mathrm{h}$, samochodu ze sztywną oraz podatną przednią częścią nadwozia.

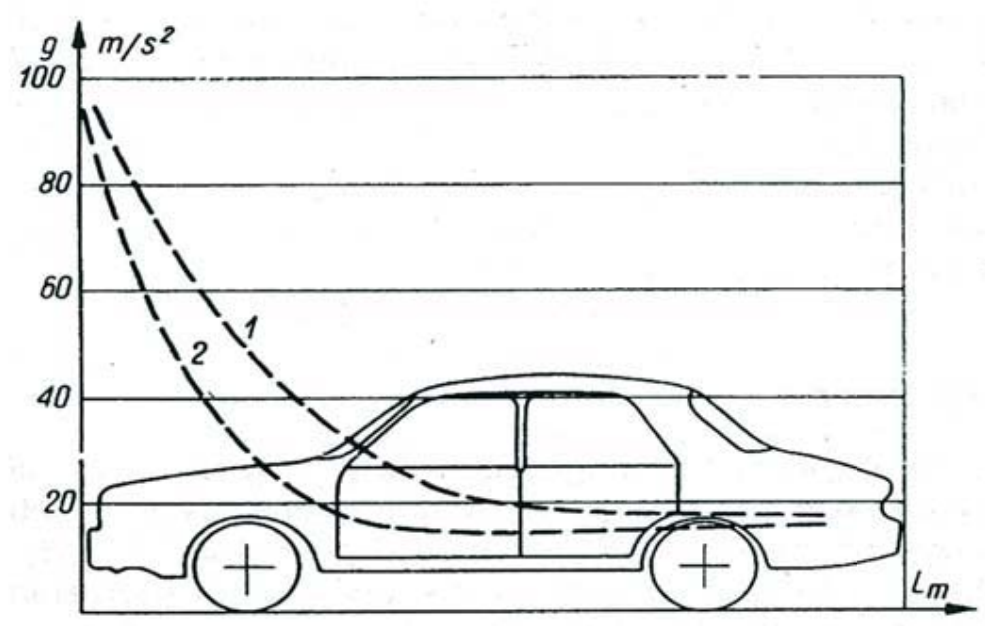

Rys. 5. Rozkład przyspieszeń nadwozia przy zderzeniu z prędkością 50km/h [4] 1 - sztywny przód nadwozia; 2 - podatny przód nadwozia

Widać wyraźnie, że wartość przeciążenia przenoszonego na przedział pasażerski w samochodzie posiadającym sztywną część przednią jest około dwukrotnie większa niż w rozwiązaniu z podatnym przodem nadwozia.

Modyfikacja rozwiązania konstrukcyjnego belek znajdujących się wewnątrz komory silnika, zaproponowana w niniejszej pracy, ma na celu osiągnięcie w/w obniżenia wartości przyspieszeń oddziałujących na pasażerów podczas zderzenia czołowego. Analiza wykresu przedstawionego na rysunku 5 pokazuje, że największą podatność na odkształcenia powinna wykazywać belka wzdłużna, zaraz za zderzakiem przednim, po czym stopniowo jej sztywność musi wzrastać tak, aby nie dopuścić do deformacji przestrzeni pasażerskiej. Elementy z tworzyw sztucznych mają niewielki wpływ na charakterystykę procesu zgniotu, [9] choć obserwuje się stosowanie nowych struktur w istotnym stopniu zwiększających sztywność nadwozia. Chodzi głównie o zastosowanie elementów z włókien węglowych i kompozytów.

Realizacja powyższych wymagań jest narzucona poprzez zróżnicowanie pola przekroju poprzecznego zaproponowanych modeli belek wzdłużnych wzdłuż ich osi. Najmniejsze pole przekroju poprzecznego znajduje się od przedniej strony pojazdu (za zderzakiem) 
a)

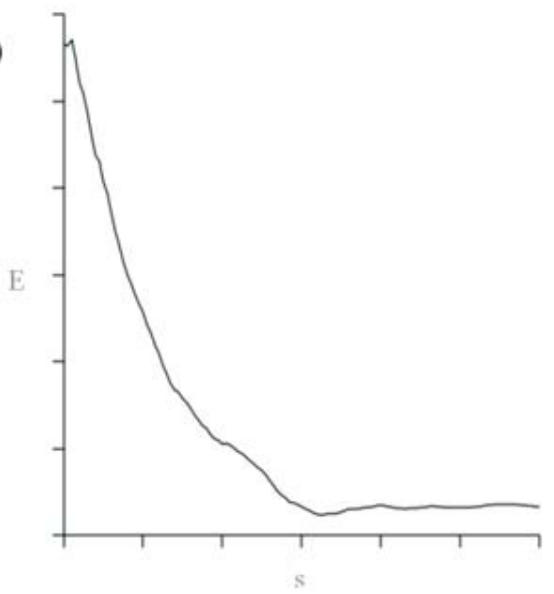

b)

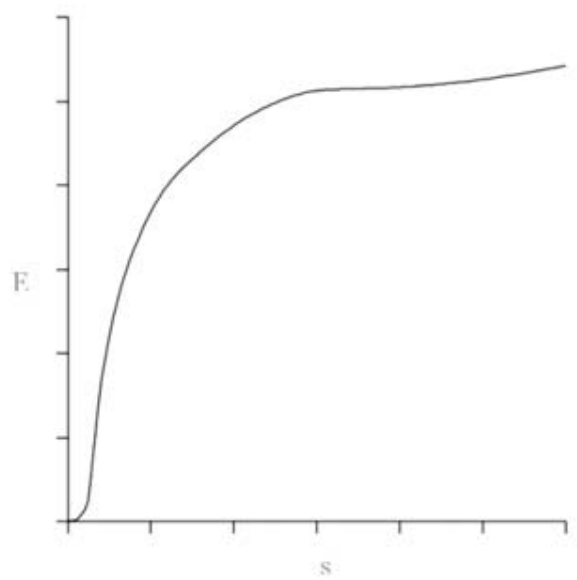

Rys. 6. Przebiegi rozpraszania energii w zależności od zgniotu [12]

Oznaczenia: a) przebieg niekorzystny; b) przebieg pożądany; E -siła; s - przemieszczenie

i powiększa się wraz ze zbliżaniem do przedziału pasażerskiego, co wpływa na stopniowe zwiększanie sztywności (zaproponowane modele belek wzdłużnych mają kształt ostrosłupa pozbawionego wierzchołka). Dla osób znajdujących się w przedziale pasażerskim niezwykle istotną sprawą rzutującą na przeżycie są występujące maksymalne przyspieszenia, wynikające z przebiegu rozpraszania energii w funkcji zgniotu (deformacji nadwozia). Rysunek 6 przedstawia charakterystyki przebiegu rozpraszania energii w zależności od deformacji nadwozia s.

Przebieg niekorzystny pokazano na rys. 6a. W takim przypadku występuje duże rozpraszanie energii w pierwszej fazie zgniatania, co skutkuje wystąpieniem dużych przyspieszeń. Rozpraszanie energii występuje głównie w pierwszej fazie. Przebieg zaprezentowany na rys. 6b. charakteryzuje się monotonicznym narastaniem wartości energii (odwzorowanej przez siłę E) wraz z postępującym odkształceniem (s). Dzięki temu energia zderzenia zostaje w sposób kontrolowany tak rozproszona przed częścią pasażerską, aby zminimalizować wartość opóźnienia oddziałującego na ludzi. Wytyczne konstrukcji nadwozi uwzględniające bezpieczeństwo bierne zawarto w [8]. Analityczne spojrzenie na rozwój konstrukcji nadwozi samochodowych i ich cech zawarto w publikacji [10], gdzie autor wskazuje na poszukiwanie kompromisu między różnymi (często sprzecznymi) wymaganiami stawianymi nadwoziom samochodów osobowych.

\section{Badania i charakterystyka zmodyfikowanych podłużnic nadwozia}

Celem pracy było opracowanie i zbadanie charakterystyk rozpraszania energii modeli podłużnic samochodu, w kształcie ostrosłupów ściętych, z których jeden wykonany był jako bryła cienkościenna, drugi o takich samych wymiarach posiadał dodatkowo wspawane wewnątrz płaskowniki wzdłuż środków ścian bocznych. Zabudowanie wzmocnień 
wewnątrz elementów wynikało z prawdopodobieństwa ich zabudowy wewnątrz profili konkretnego samochodu. Zaproponowane modele belek wzdłużnych, użyte również jako próbki do badań, przedstawiono na rysunkach 8 . Założony kształt zaproponowanych modeli wynikał z odwzorowania kształtu belek podsilnikowych (podłużnic) rzeczywistego samochodu, którego przód przedstawiono na rysunku 7. Przedstawiony rysunek stanowi bazę do analiz numerycznych prowadzonych w innych pracach dyplomowych uwzględniających wyniki opisane w niniejszej publikacji.

Badanie polegało na wyznaczeniu charakterystyk zgniotu próbki 1 - nie posiadającej wzmocnień oraz próbki 2 - wzmocnionej płaskownikami i porównaniu ich ze sobą oraz odniesieniu do pożądanego przebiegu rozpraszania energii zderzenia przedstawionego na rys. $6 b$.

Parametry maszyny wytrzymałościowej Instron 1197 zostały ustawione identycznie dla obu próbek:

- zakres obciążenia: $200 \mathrm{kN}$

- prędkość zgniotu: $50 \mathrm{~mm} / \mathrm{min}$

- zakres zgniotu: $100 \mathrm{~mm}$

Jako pierwsza została poddana badaniu próbka 1 - bez wzmocnionej struktury, następnie próbka 2 - wzmocniona. Charakterystyki wykonane na podstawie pomiarów przedstawiają poniższe wykresy rysunki 9 i 10.

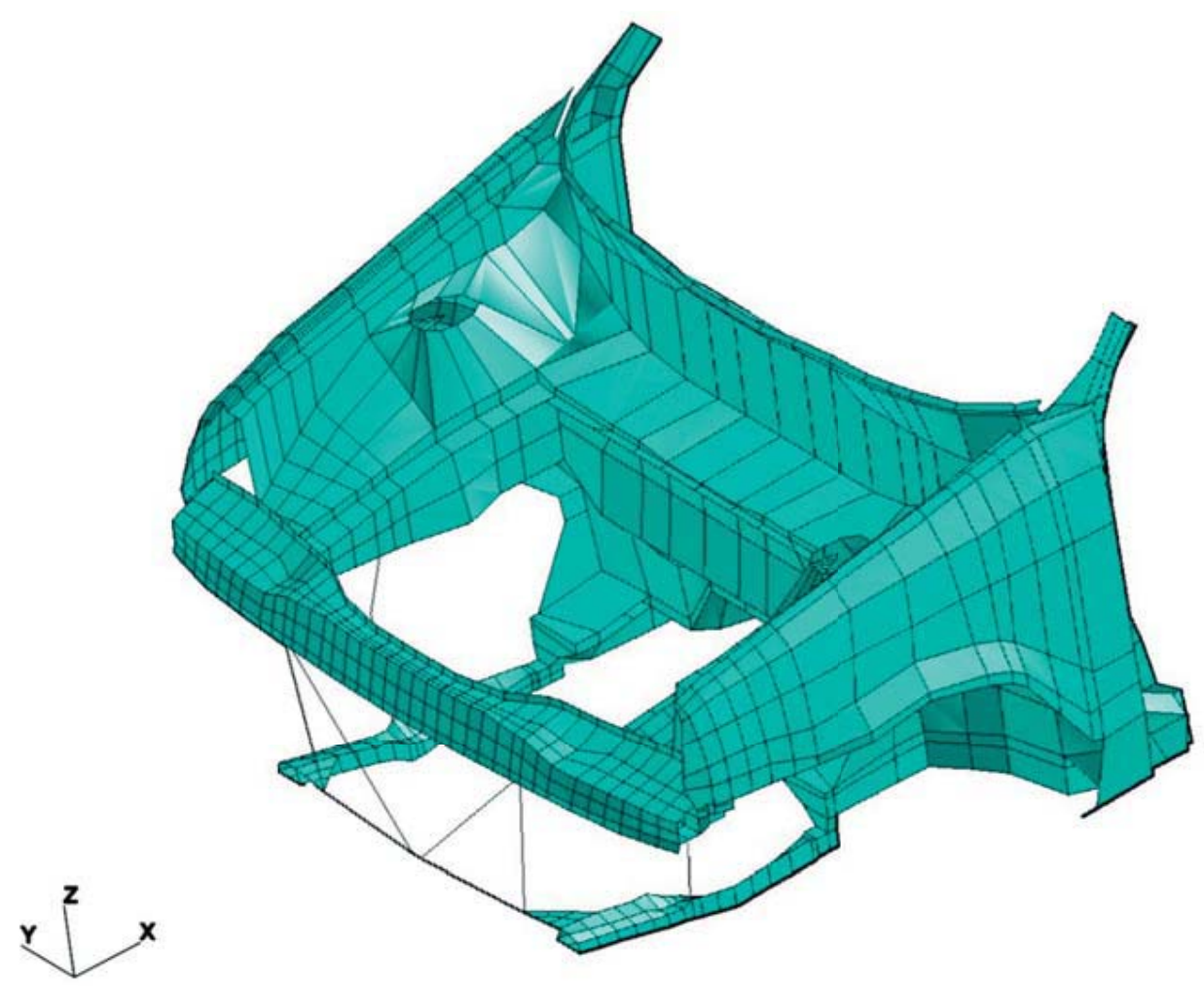

Rys. 7. Zamodelowany przód nadwozia samochodu osobowego 


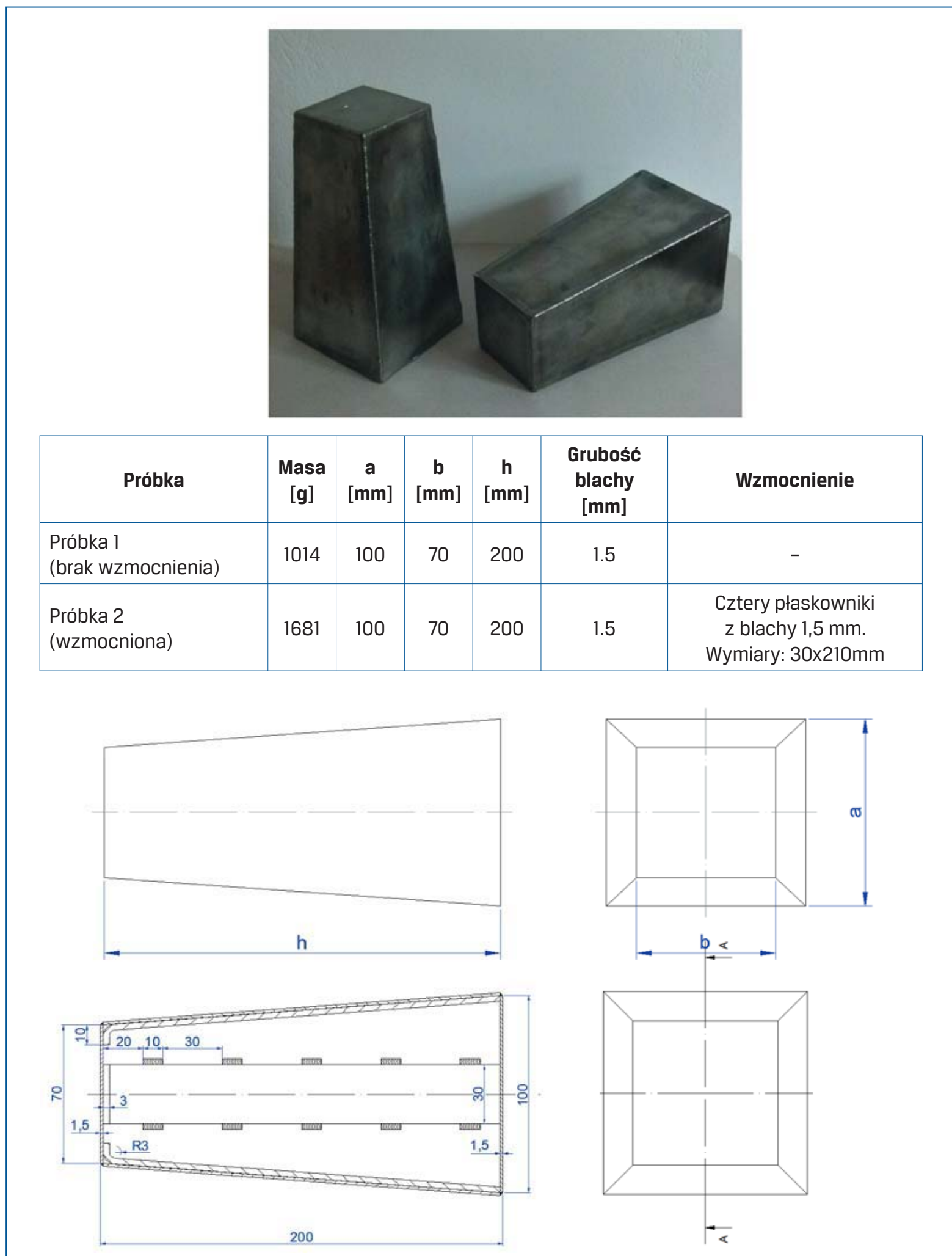

Rys. 8. Zaproponowane stalowe modele belek wzdłużnych, użyte jako próbkỉ do badań 

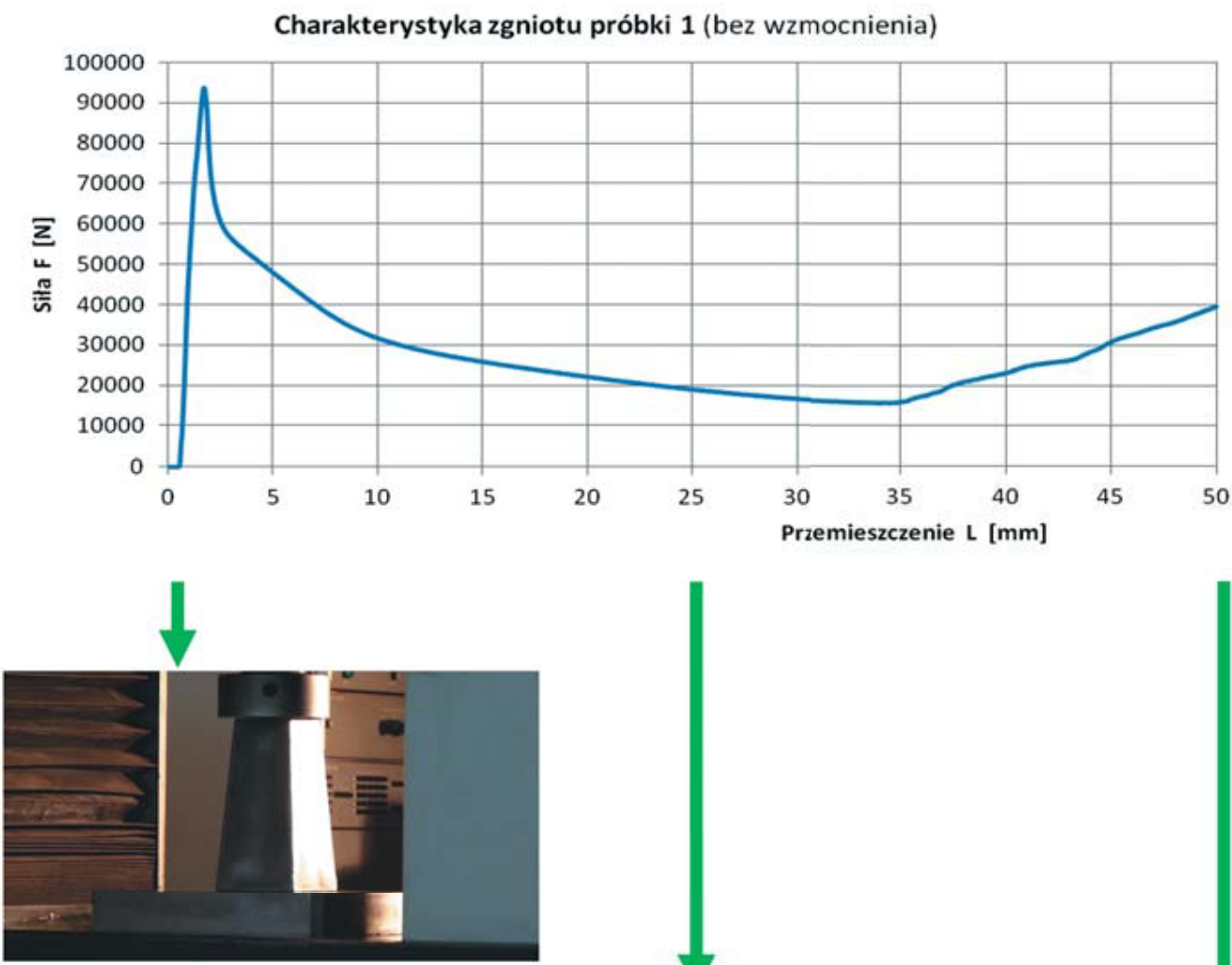

Faza początkowa

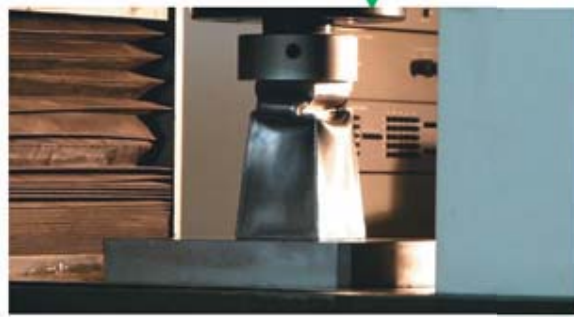

Faza środkowa

Maksymalna wartość obciążenia podczas próby wyniosla: $\mathbf{9 3 , 7 8 4} \mathbf{k N}$

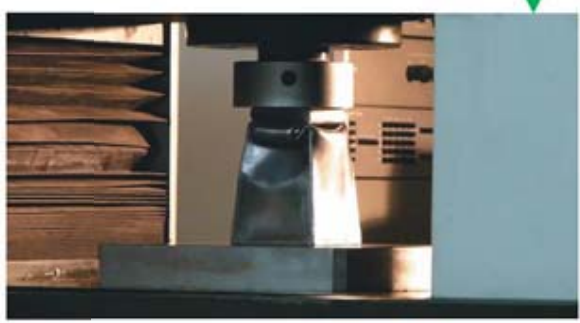

Fazakońcowa

Rys. 9. Przebieg zgniotu próbki 1 


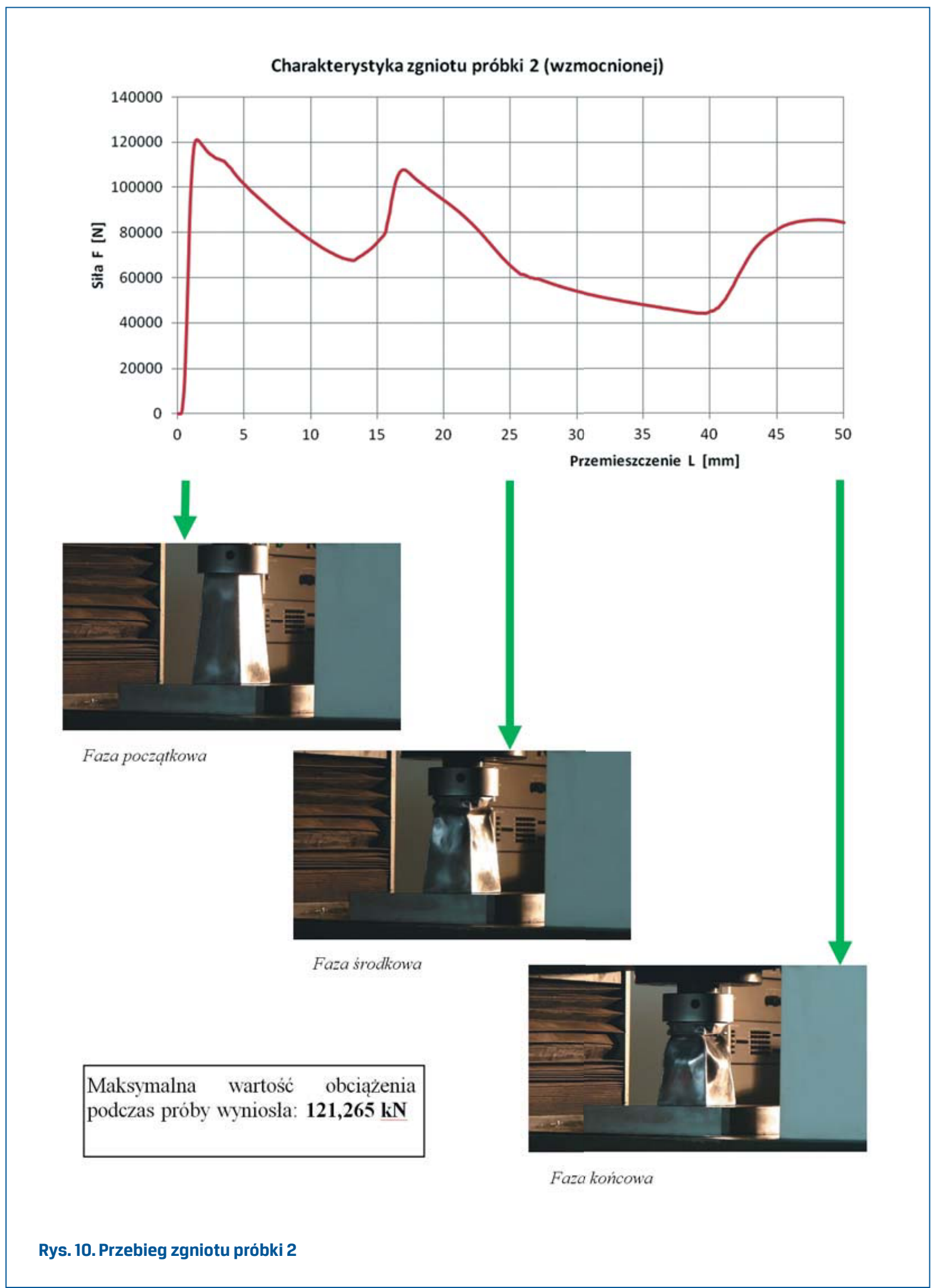




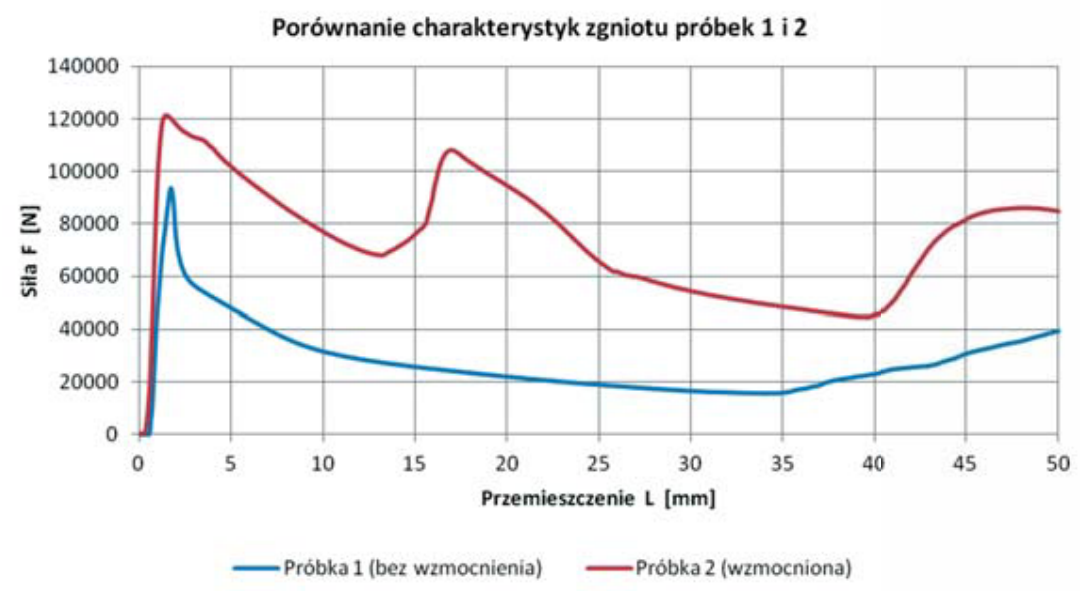

Rys.11. Porównanie charakterystyk zgniotu próbek 1 i 2

Porównanie charakterystyk dyssypacji energii podczas zgniotu próbek 1 i 2

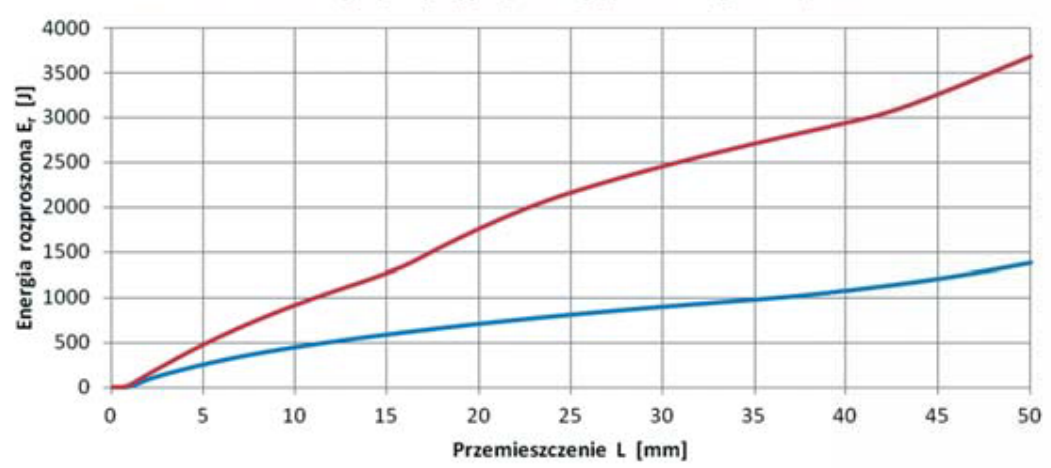

—Próbka 1 (bez wzmocnienia) —Próbka 2 (wzmocniona)

Rys. 12. Porównanie charakterystyk rozpraszania energii (dyssypacji) próbek 1 i 2

Wartości energii rozproszonej dla poszczególnych faz zgniotu próbek 1 i 2

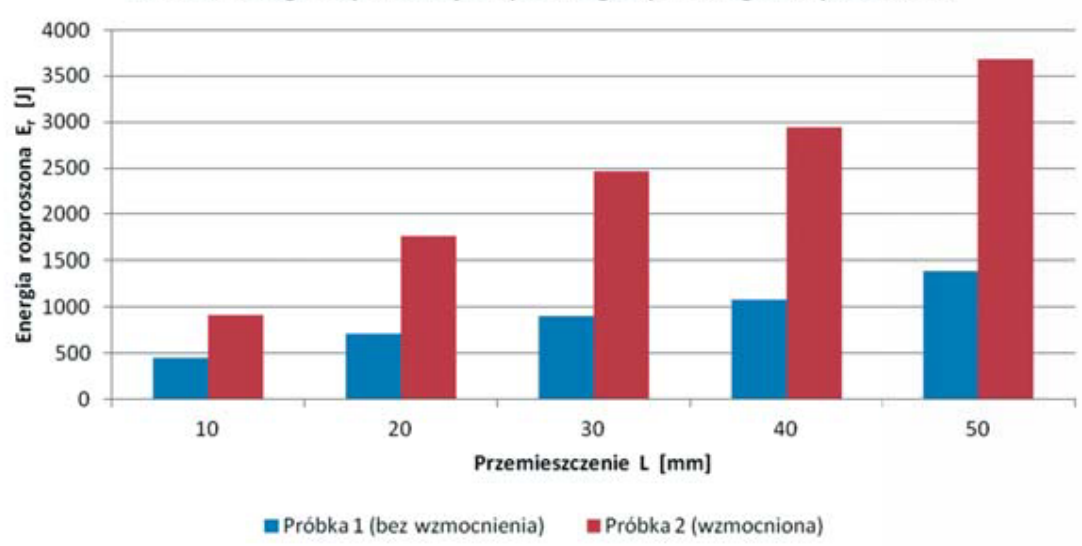

Rys. 13. Zmienność wartości rozpraszanej energii w zależności od zgniotu 
Oprócz charakterystyk zgniotu próbek, na podstawie wyników pomiarów wykonane zostały także przebiegi rozpraszania energii.

Energia rozproszona podczas próby wyliczona została jako pole powierzchni pod wykresem zależności obciążenia F od przemieszczenia L.

Porównanie charakterystyk zgniotu przedstawione jest na rysunku 11, natomiast proces rozpraszania energii dla obu próbek zestawiają wykresy 12 i 13.

\section{Analiza wyników i wnioski}

Na podstawie przeprowadzonych badań widać wyraźną różnicę przebiegu charakterystyk zgniotu dla próbki 1 (niewzmocnionej) oraz 2 (wzmocnionej). Maksymalna wartość siły ściskającej uzyskanej w przypadku próbki 1 wynosi około 93,7 kN, natomiast dla próbki 2 jest to $121,2 \mathrm{kN}$. Analiza tego fragmentu charakterystyk wskazuje także różnicę w sztywności obu próbek. Maksymalna wartość obciążenia ściskającego dla próbki wzmocnionej została osiągnięta "wcześniej" - przy mniejszej wartości przemieszczenia L, co potwierdza jej zwiększoną sztywność spowodowaną wspawanymi płaskownikami. Ponadto, charakterystyka zgniotu wzmocnionej próbki pokazuje wzrost wartości siły ściskającej na wysokości spawów łączących płaskowniki ze ścianami próbki (lokalny wzrost obciążenia do wartości około 107 kN). Dla porównania, w przypadku próbki 1, po osiągnięciu maksymalnej wartości obciążenia, jego wartość spada w sposób ciągły do przemieszczenia około $35 \mathrm{~mm}$ (wartość siły: $18 \mathrm{kN}$ ).

Porównując wykres z rys. 12. (przedstawiający charakterystyki rozpraszania energii otrzymane z pomiarów) z pożądanym przebiegiem dyssypacji energii (rys. 6), można stwierdzić analogię w postaci monotonicznego narastania energii w funkcji przemieszczenia. Świadczy to o poprawności zaproponowanej koncepcji konstrukcji belki wzdłużnej. Zjawisko rozpraszania energii podczas zgniotu jest wyraźniejsze w przypadku próbki wzmocnionej (2), co dowodzi skuteczności wprowadzenia modyfikacji w postaci wspawanych płaskowników. Ponadto udowadnia, że przebieg dyssypacji energii można kontrolować i "programować" w zależności od wymagań konstrukcyjnych, poprzez dobór materiału, z jakiego wykonany jest element energochłonny, wymiarów oraz użytych wzmocnień.

Zaletą proponowanej w niniejszej pracy modyfikacji belki podłużnicowej do samochodu osobowego, jest możliwość stosunkowo łatwego „programowania" charakterystyki rozpraszania energii zgniotu. Na rysunku 10 widoczny jest gwałtowny spadek wartości siły obciążającej zaraz po osiągnięciu pierwszego maksimum, spowodowany osiągnięciem pierwszego spawu. Zmianę tej charakterystyki na bardziej korzystną umożliwiłoby najprawdopodobniej zbliżenie spawu do górnej podstawy ostrosłupa ściętego stanowiącego profil belki wzdłużnej oraz zaprogramowanie odległości pomiędzy poszczególnymi spawami. Można by zastosować również inną metodę połączenia wzmocnienia ze ścianą profilu, np. w postaci zgrzewania punktowego według założonej sekwencji. 


\section{Literatura}

[1] Automotive News Europe, 17/2005.

[2] Materiały szkoleniowe Daimler AG 1999.

[3] MAIOLI M: Function versus appearance: The interaction between customer, stylist and engineer in vehicle design. International Journal of Vehicle Design nr 5/1984.

[4] ZIELIŃSKI A.: Konstrukcja nadwozi samochodów osobowych i pochodnych, WKt, Warszawa 2008.

[5] PAWtOWSKI ].: Nadwozia samochodowe, WKL, Warszawa 1978.

[6] www.program.ratowniczy.pl, Systemy bezpieczeństwa.

[7] www.e-autonaprawa.pl , Nadwozia w kolizjach drogowych.

[8] KAPIŃSKI S.: Ksztaltowanie elementów nadwozi samochodowych, WKŁ Warszawa 1998.

[9] DOBROSZ K., MATYSIAK A.: Tworzywa sztuczne w pojazdach samochodowych, WKt, Warszawa 1982.

[10] ZIELIŃSKI A.: Ewolucja nadwozi małych samochodów, Zeszyty naukowe OBR SM BOSMAL nr 4 /1994.

[11] WICHER J. Bezpieczeństwo samochodów i ruchu drogowego, WKił Warszawa 2002.

[12] Prace własne autora. Szerzej na ten temat: ROMANISZYN K.M.: Wpływ struktury przodu nadwozia na energochłonność, Zeszyty naukowe Politechniki Świętokrzyskiej, Mechanika nr 84/2006, ss. 287-293, (B). 